\title{
The Differential Effect Of Auditor Type on the Value Relevance of Earnings and Book Values: Evidence from Listed Firms in Nigeria
}

\author{
Asmau Mahmood Baffa \\ Department of Accounting, Bayero University Kano, Nigeria \\ Jibril Ibrahim Yero \\ Department of Accounting, Ahmadu Bello University, Zaria, Nigeria
}

\begin{abstract}
A determining factor of investors' decision is mostly represented by the auditing of financial statements carried out by a Big4 company, because investors appreciate the quality of the auditing service in terms of image, size and reputation of the auditing firm. This study examines the differential effect of auditor type classified as Single Big4 audit firm; Single Non-Big4 audit firm; and joint audit team of Big4/Non-Big4 audit firms, on the value relevance of earnings and book values of listed firms in Nigeria. A sample of one hundred and seventeen listed (117) firms trading on the floor of Nigerian Stock Exchange from 2009 to 2015 were examined. The study adopted Ohlson model (1995) modified to include auditor type variable and control variables. A simultaneous pooled OLS regression using the Seemingly Unrelated Regression Estimates (SUEST) approach was utilized in running the analysis of all relevant data collected. The findings of the study reveal that while Nigerian investors perceive the earnings of firms audited by a Single Big4 to be of high quality, they seem indifferent as to whether it is audited by a joint audit team of Big4/Non-big4, or a Single Non-Big4 audit firm. The study therefore recommends that investors looking for more value relevant EPS should focus on firms audited by single Big4, since they are more likely to have greater value relevant earnings with stronger positive connection to price.
\end{abstract}

Keywords: Joint audit, single audit firm, share prices, earnings, book values, Nigeria

\section{Introduction}

Value relevance research is primarily carried out in order to examine whether companies' financial statements provide users of financial reports with high quality and valuable accounting information that will enable them to make informed decisions. Value relevance of accounting information addresses the degree to which accounting information is impounded in share prices. Such researches examine the association between share prices or returns as a dependent variable, and a set of independent variables (earnings, book values, and any other relevant accounting information). Thus, accounting information is considered value relevant from an investor's perspective, when there is a significant statistical association between the independent variables with the dependent variable. Such researches have empirically established that the higher the association, the higher the financial reporting quality, and the more reliable and useful the accounting numbers reported are, to the valuation decisions of investors (Francis \& Schipper, 1999; Barth, Landsman \& Lang, 2006; Banimahd, Poorzamani \& Ahmadi, 2013).

Accordingly, when making decisions about capital allocation, investors need to know that the financial information they are given is credible and reliable (Schilder, 2011). Empirically, an accounting amount is deemed value relevant with some reliability if it increases the power of the estimating equation in assessing market values (Barth, et al., 2006). But, the reliability of the accounting information provided in the audited financial report is the crux of the problem faced by users of financial statements especially investors in their decision making process. Auditors, by doing audits in accordance with the Generally Accepted Auditing Standards (GAAS), will attest to the fairness of corporate financial reports by detecting and reporting material deviations from the generally accepted accounting standards to various stakeholders (Lai, Lin, Li \& Wu, 2009). 
Users of financial information therefore, place their reliance on the information contained in audit reports as a platform for their decision making purpose largely based on the assurance that the information obtained from the audited financial statements is reasonably accurate, complete and unbiased. This is because audited annual reports generally represent the most significant feature of the audit process used by auditors to offer an independent, objective and professional opinion regarding the true and fair view of the financial position and performance presented by the company's management in the financial statements (Al-Thuneibat, Khamees, \& Al-Fayoumi, 2008). Moreover, the effective functioning of the capital markets is achievable only when investors and other stakeholders have sufficient confidence in the audited financial statements.

As such, the major rationale proposed in the literature for a company to hire an auditor and to accept the additional monitoring by an external party, is derived from the Agency Theory, because, the choice of a specific auditor is linked with arising agency costs, resulting in directors of companies making this decision with the goal of reducing agency costs caused by several information asymmetries arising in a company's environment. Accordingly, the ability of an external auditor to qualify an audit opinion indicates some level of independence and quality. Consequently it is expected that the type of auditor can be used in gauging the reliability of audited financial reports and hence impact positively on the value relevance of accounting information by sending a positive signal to capital market.

Auditor type is defined in this study as the category of independent audit firm(s) engaged by an entity to perform its audit in accordance with statutory regulation and professional requirements. The audit firm in accounting literature is broadly categorized according to variations in firm size, mostly in line with either big $x /$ non-big $x$ firm or a joint audit team. As such, the study further categorizes auditor type into three classes; Single Big4, Single Non-big4 and joint audit team of Big4/Nonbig4 audit firms looking at the audit firm structure in Nigeria. The single audit firm category refers to the engagement of one distinct audit firm either a Big4 or a Non-big 4 firm, while the joint audit refers to the engagement of two audit firms of Big4/Non-big4 audit firm. However, it should be noted that joint audit generally refers to the engagement of either a Big4/Big4 or Big4/Non-big4 audit firms.

In the accounting literature, a significant issue frequently raised is whether opinion of auditors from large firms differs to a large extent from those of auditors engaged by other firms. Extant literature attempted to find the relationship between auditor type (categorized using the Big $x$ / Non-Big $x$ dichotomy) and audit independence with majority of the results of these researches concluding that big audit firms have more independence and higher quality in their audit work (De-Angelo 1981; Francis \& Wilson, 1988; DeFond, 1993; Francis \& Yu, 2009; Chen, Lin \& Lin, 2008; Cheng, Liu, \& Chien, 2009). The result of studies that evaluated the impact of joint audits on audit quality such as Ratzinger-Sakel, Lesage and Kettunen (2012) and Zerni, Haapamaki, Jarvinen and Neimi (2012) showed contradictory evidence, with the former indicating a negative significant relationship and the latter having a positive significant relationship.

Furthermore, other studies which examined the effect of auditor type categorized as single audit firms (big 4 or non-big 4) and joint audits (big 4 - big 4; or/and big 4 - non big 4) such as the studies of Deng, Lu, Simunic and Ye (2012); Alsadoun and Aljabir (2014); Guo, Koch and Zhu (2015) and Lobo, Pangam, Zhang and Casta (2016) on audit quality, cost of equity capital, conservatism, audit market structure and consumer surplus, respectively, obtained inconclusive findings. The above mentioned studies focused on investigating the impact of joint audit on financial reporting and audit quality, without looking at the investors' perception in the pricing of firms based on the auditor type. However, related studies on auditor type and value relevance of earnings and book values of Lee and Lee (2013) in Taiwan and that of Okolie (2014) in Nigeria considered auditor type using the Big4/Non-big4 dichotomy. This study uses a different approach considering the audit firm structure in Nigeria by classifying the auditor type as Single Big4; Single Non-big4; and joint audit team of Big4/Non-big4. The study also assesses the differential effects of these audit firm categories in addition to their effect on reported earnings and book values of equity. To the best of the researcher's knowledge, no study has used these two approaches.

Nigeria's economy is considered as the largest in Africa, and companies listed on the stock exchange can access longterm capital from a wide range of local and international investors. Listed firms on the Nigerian Stock Exchange (NSE) enjoy the benefits of trading domestically and globally, thereby, helping to distribute risk which gives initial investors the chance to realize some or all of their investments. Interest in the Nigerian stock market has grown as the investment culture in Nigeria has shifted to the capital market due to steps taken by the government to foster its development especially in the $20^{\text {th }}$ century. As such, in order for the findings of the study to be generalized and for more robust and meaningful conclusions to be drawn, all listed firms actively trading on the floor of the stock exchange for the entire period of the study (2009 to 2015) were considered. 
In light of the foregoing, a research of this nature can be considered relevant and justified, given the fact that the audit firm is the most significant factor attributed to the reliability of audited financial statements in making decisions by users. Therefore, this paper contributes to the literature on different audit firm structures and their effects on the value relevance of earnings and book values in Nigeria. In order to achieve this aim, the study assesses whether Nigerian investors distinguish between audited financial reports derived from Single Big4 audit; joint audit team of 'Big 4/non Big4'; or Single Non-Big4 audit firms, when examining such reports for decision making. That is, do users' agree a Big4 audit firm's - audit report is more value relevant than Single Non-Big4 or a joint team of Big4/Non-Big 4 audit firms by testing the following null hypotheses:

$\mathrm{H}_{01 \mathrm{a}}$ : $\quad$ Reported earnings of Nigerian listed firms audited by a joint audit team of Big4/ Non-big4 is not significantly value relevant to Nigerian capital market investors.

$\mathrm{H}_{01 \mathrm{~b}}$ : $\quad$ Reported book-value of Nigerian listed firms audited by a joint audit team of Big4/Non-Big4 is not significantly value relevant to Nigerian capital market investors.

$\mathrm{H}_{02 \mathrm{a}}$ : $\quad$ Reported earnings of Nigerian listed firms audited by a single Big4 firm is not significantly value relevant to Nigerian capital market investors

$\mathrm{H}_{02 \mathrm{~b}}$ : $\quad$ Reported book-value of Nigerian listed firms audited by a single Big4 firm is not significantly value relevant to Nigerian capital market investors

$\mathrm{H}_{03 a}$ : $\quad$ Reported earnings of Nigerian listed firms audited by a single non-Big4 firm is not significantly value relevant to Nigerian capital market investors

$\mathrm{H}_{03 \mathrm{~b}}$ : $\quad$ Reported book-value of Nigerian listed firms audited by a single non-Big4 firm is not significantly value relevant to Nigerian capital market investors

$\mathrm{H}_{04 a}$ : The value relevance of reported earnings for firms audited by a single Big4 firm is not significantly different from the value relevance of reported earnings for firms audited by a joint audit team of Big4/Non-Big4

$\mathrm{H}_{04 b}$ : $\quad$ The value relevance of reported book-value for firms audited by a single Big4 audit firm is not significantly different from the value relevance of reported bookvalue for firms audited by a joint audit team of Big4/Non-Big4

Ho5a: $\quad$ The value relevance of reported earnings for firms audited by a single Non-Big4 auditor is not significantly different from the value relevance of reported earnings for firms audited by a joint audit team of Big4 and Non-Big4

$\mathrm{H}_{05 b}$ : The value relevance of reported book-value for firms audited by a single Non-

Big4 auditor is not significantly different from the value relevance of reported bookvalue for firms audited by a joint audit team of Big4 and Non-Big4

$\mathrm{H}_{06 a}$ : The value relevance of reported earnings for firms audited by a single Big4 is not significantly different from the value relevance of reported earnings for firms audited by a single Non-Big4

Ho6b: $\quad$ The value relevance of reported book-value for firms audited by a single Big4 audit firm is not significantly different from the value relevance of reported bookvalue for firms audited by a single Non-Big4

The remainder of the paper is organized as follows: Section 2 illustrates audit and accounting environment in Nigeria as well as discusses relevant prior studies. Section 3 describes the research methodology. Section 4 presents the empirical results of this study. Finally, Section 5 gives a brief summary of findings, and conclusion.

\section{Literature Review and Conceptual Issues}


External auditors are entrusted by law with conducting statutory audits by offering an opinion on whether the financial statements reflect a true and fair view of the company's state of affairs. The objectivity of auditors in the course of their duties therefore, is of paramount importance as it guarantees independence and compels trust and confidence in the users of the financial statements. Audit quality plays an important role in upholding an efficient market environment because it strengthens confidence in the credibility and integrity of financial statements which is essential for well-functioning markets (Farouk \& Hassan, 2014) therefore, auditors are expected to be independent and objective at all times. Thus, the role of auditing is to improve the quality of financial statements as high quality reporting can reduce information asymmetry problems between the firm and providers of financing.

\subsection{Regulatory Framework of Auditing Practice in Nigeria}

A substantial proportion of practicing auditors in Nigeria are members of the Institute of Chartered Accountants of Nigeria (ICAN) and Association of National Accountants of Nigeria (ANAN). These professional bodies have rules guiding the conduct of members in practice. In the same vein, public limited companies in Nigeria are mandated by law to have their financial statements audited by an independent public accountant. Even though the responsibility for the preparation and presentation of financial statements of companies lie on the company directors, they have to be prepared in accordance with International Financial Reporting Standards (IFRS) and the provisions of Section 357 (1) of CAP C20 Laws of the Federation of Nigeria (LFN) 2004, and the Financial Reporting Council of Nigeria Act, No 6 (2011). This is to enable the preparation of the financial statements to be free from material misstatements. Similarly, the external auditor is responsible for auditing the financial statements of his clients in accordance with Generally Accepted Auditing Standards (GAAS) to offer reasonable assurance that the financial statements give a true and fair view of the companies' state of affairs (Olowookere \& Inneh, 2016).

In Nigeria, the International Standards on Auditing (ISA) are mandatory for companies quoted on the Nigeria Stock Exchange (NSE) where Nigerian Auditing Standards do not exist. But due to the peculiarity of the Nigerian environment in July, 2006, nine (9) Nigerian Standards on Auditing (NSA) were issued. These claimed priority over the ISAs in the Nigerian context. The Nigerian Standards on Auditing (NSAs) are based on International Standards on Auditing (ISAs) of the International Auditing and Assurance Standards Board, published by the International Federation of Accountants (IFAC) in July 2012 and is used with permission of IFAC. The Nigerian Standard on Auditing (NSA) deals with the independent auditor's overall responsibilities when conducting an audit of financial statements in accordance with NSAs. Specifically, it sets out the overall objectives of the independent auditor and explains the nature and scope of an audit designed to enable the independent auditor to meet those objectives. NSAs became effective for audits of financial statements for periods beginning on/or after April, 2013 (NSA, 2013:4).

According to Olowookere and Inneh (2016), Nigeria has two thousand $(2,000)$ audit firms providing audit services to both listed and unlisted companies in the country. However, notwithstanding the availability of various audit suppliers, statistically, the audit market is dominated by four large audit firms; Akintola Williams Deloitte (AKWD); Ernst and Young (E \&Y); Klynveld, Peat, Marwick and Goerdeler (KPMG); and PriceWaterhouse Coopers (PWC). The 'Big Four' international accounting firms audit more than 90 percent of listed companies in Nigeria, with the remaining 10 percent audited by 15 national firms with international affiliation. Globally, the market share gap between the Big Four (Delloitte, E \& Y, KPMG and PWC) and other firms have become wider potentially reducing the possibility for the small firms to become significant service providers in capital markets worldwide.

\subsection{Audit Firm Size}

Theoretically De Angelo (1981) states that the relationship between audit quality and auditor's size has been analyzed with observations positing that large auditors will have more clients and their total fees will be allocated among those clients. Also, she argued that large auditors can contain the loss of a client and therefore, will provide higher quality of audit. According to Jeong and Rho (2004), large international accounting firms have established brand reputation and have motives to maintain it by providing high-quality audit, as lack of financial affiliation with clients makes bigger auditors more independent. This independence provides big auditors with stronger negotiation stance with their chart compared with smaller audit firms (Nelson, Elliott \& Tarpley, 2002).

Similarly, Woodland and Reynolds (2003) suggest that perhaps the most commonly used indirect measure of audit quality is the audit firm size dichotomized as Big $x$ versus Non-Big $x$ dichotomy. Theoretical motivation for Big $x$ / Non-Big $x$ 
dichotomy as an indirect measure of audit quality is strong, and empirical evidence on its performance generally supports its use (Simunic, 1980; DeAngelo, 1981; Francis \& Wilson, 1988; O'Keefe et al. 1994; Moizer, 1997; Becker, Defond, Jiambalvo \& Subramanyam 1998; Bauwhede et al., 2000; DeFond, Raghunandan, \& Subramanyam, 2002, Krishnan \& Schauer, 2000; Ebrahim 2001; Ferguson, Seow, \& Young, 2003; Krishnan, 2003; Hussainey, 2009; Dang, Brown \& McCullough, 2011; Lin \& Tepalagul, 2012; Farouk \& Hassan, 2014; Okolie \& Izedonmi, 2014). Also, Colbert and Murray (1998) posit that one of the reasons why the evaluation of the relationship between auditor size using the Big $x$ / Non-Big $x$ dichotomy is important, is because users of audited financial statements can easily employ this observable dichotomy in their assessments of audit quality and the resulting financial statement credibility.

DeAngelo (1981) and Francis (2004) posit that accounting firm size is mostly used as a proxy for quality because no single client is important to a large auditor, and the auditor has a greater reputation to lose their clients if they misreport. However, an accounting firm with only one client may plausibly conclude that they have more to gain by going along with their client and misreporting than by being tough and potentially getting fired.

\subsubsection{Joint Audit}

Joint audit can be defined as an audit in which financial statements are audited by two independent auditors with any of the following characteristics which may differ across countries: shared audit effort; one single auditor's report signed by both auditors; and joint liability for both auditors (Ratzinger-Sakel, Audosset-Coulier, Kettunen, \& Lesage, 2012). Generally, joint audit involves the appointment of a lead audit firm and a support audit firm by a client with the mandate to jointly carry out the audit of a given entity within a defined time period usually a year. A joint audit is an audit on a legal entity (the auditee) by two or more auditors to produce a single audit report, thereby sharing responsibility for the audit. A typical joint audit has audit planning performed jointly and fieldwork allocated to the auditors.

Joint audits contribute positively to audit quality, thereby giving credibility to financial statements because by appointing two different audit firms, the client firm allows audit firms to rotate, safeguarding auditor independence, but also retaining the remaining auditor's knowledge and understanding of the client's business operations, thereby avoiding the potential downside of auditor rotation of a discontinuity in competence. Additionally, the threat to auditor independence due to economic bonding is likely to be a less significant issue with the joint audit approach than it is with the single auditor approach, because, in joint audits, the audit fees and lucrative consulting fees are distributed between two different audit firms (i.e. there are lower fees at stake). Consequently, the two different audit firms may take a stronger stand against pressure from the managers and/or controlling owners and report their opinions on the clients' accounts more independently (Zerni, Haapamaki, Jarvinen, \& Neimi, 2012).

Joint audits are not uncommon as since 1966, France has mandated joint audits of public companies. Similarly, joint audits are mandated for the financial services sector in South Africa. Various countries, such as India, Germany, Switzerland, and the U.K., have proposed voluntary joint audits. Several studies have analyzed the effect of joint audit regulations on audit quality. Francis et al. (2009) examine joint audit and its effects on audit quality in France, where joint audits are mandatory, and report evidence consistent with an agency-driven demand to employ higher quality auditor pairs. They also find that client firms employing higher quality auditor pairs have smaller abnormal income-increasing accruals than the firms that do not use Big 4 auditors (i.e. those that use two non-Big 4 auditors) and that this effect is strongest when client firms use two Big 4 auditors. In Nigeria, joint audit is voluntary.

\subsection{Earnings, Book Values and Market Value}

Market value is one of the most important factors which affect investors' investment decision. According to Sharma (2011), a market value is the price of a single unit of saleable shares of a company, which represents the balance struck between the buyers and sellers at a particular moment, viewed as the collective wisdom and knowledge of the market. Changes in prices of shares determine the return on investment on the shares. The market value is therefore, considered as one of the most important factors which affect investors' investment decisions. The market value is mainly determined by the forces of demand and supply of a particular security in the market, and can be obtained from the stock exchange market (Zahir \& Khanna, 1982).

Suggestions from empirical studies reveal that Earnings per Share (EPS) is one of the strongest factors affecting the share price or market value (Sharma, 2011). The pioneers of the studies on determinants of share price were Collins (1957) and Gordon (1959). Both of them in their independent studies identified earnings as one of the factors influencing share prices. 
Beaver (1998) postulates that current period earnings provide information to predict future periods' earnings. The future periods' earnings provide information to develop expectations about dividends in future periods. This in turn provides information to determine share value and hence the share price. In an ideal situation, the difference between the book and market values (share price) of equity is minimal (Barth, 1991), but in more pragmatic settings, there have always been cases where a considerable variance exists between the market and book value of a business.

Empirical studies have provided evidences of EPS and BVPS being significantly value relevant to users of accounting information, however, some of these studies indicate EPS being more value relevant than BVPS (e.g. El-Shamy \& Kayed, 2005; Keener, 2011; Shamki \& Abdulrahman, 2012;) while others indicate BVPS being more value relevant than EPS (e.g. Gee-Jung \& Kwon, 2009; Qua \& Zhang, 2012; Chandrapala, 2012; Aleksanyan \& Karim, 2013). Thus, contemporary researches of value relevance are now focused on finding out which of these two variables (EPS or BVPS) is more value relevant to investors, with this study also seeking to provide an empirical evidence in this line particularly as it relates to auditor type of listed firms in Nigeria.

\subsection{Auditor Type and Market Value}

An influencing factor of the share price is mostly represented by the auditing of financial statements carried out by a Big 4 company, because investors appreciate the quality of the auditing service in terms of image, size and reputation of the auditing company (Martinez, Vico, \& Benau 2004; Robu \& Robu, 2015). The auditors of a company in the Big 4, considered a large company, are allowed to spend much time with training and getting to know the latest technologies that are used in the field, thus developing their professional competences. Also, due to the fact that a company in the Big 4 does not depend on a single client, it can resist the pressures of the client in terms of opinion freedom (Boone, Khurana \& Raman, 2010). Thus, if a listed company aims to increase its share price, it can choose a famous auditing company known by investors.

Investigating the market reaction to auditor switching from big 4 to third-tier small accounting firms Chang, Cheng and Reichelt (2010) used two separate sample periods of regulatory changes (2002 to 2006). The result showed a relatively more positive stock market reaction to clients switching from a big 4 to a smaller third-tier auditor in period 2 . When an audit quality is decreasing, this relatively more positive reaction in period 2 reflects companies seeking better services rather than a lower audit fee. In examining whether audit quality can increase the value relevance of fair value accounting, the study results of Kang-Tao and Ying-Li (2011) indicate that fair value accounting information has incremental value relevance and Big 4 auditing firms can improve the value relevance of fair value accounting information.

The joint audit study of Holm and Thingaard (2011) and Ratzinger-Sakel et al. (2012) examine whether joint audit impacts audit quality of non-financial companies listed on the Copenhagen Stock Exchange (CSE) in the Danish setting. Their findings confirm that joint audits do not have an impact on audit quality, as measured by the level of abnormal accruals, in Denmark. However, the study of Zerni et al. (2012) on the impact of voluntary joint audit on audit quality of listed nonfinancial companies in the Swedish setting for the 2001- 2007 period, suggests that companies opting voluntarily for joint audits have a higher degree of earnings conservatism, lower abnormal accruals (proxy measures for audit quality), better credit ratings and lower risk forecasts of becoming insolvent within the next year than other firms (proxy measures for perceived audit quality).

The findings of Zerni et al. are consistent with the view that joint audits improve both audit quality and perceived audit quality. The authors acknowledge that opting for voluntary joint audit is not a random choice, as Swedish minority shareholder protection legislation stipulates that minority shareholders who have, in total, at least 10 per cent of a firm's shares have the right to require the appointment of a minority auditor. Hence the joint audit decision might be driven by minority shareholders who prefer a higher degree of conservatism in the firm's accounting decisions.

Assessing the value relevance of the audit report, auditor type and auditor tenure in Iran, Banimahd, Poorzamani and Ahmadi (2013) used multiple regression analysis approach (Ohlson model - 1995) and the results obtained indicate that audit report and audit quality is not valued by the capital market in Iran. However, auditor type (audit firm size) was found to be positively significant suggesting that firms audited by public audit organizations give a positive signal and lead to the market reaction in the Iranian capital market over those using private audit firms. Lee and Lee (2013) examined whether big 4 firms improve the value relevance of earnings and equity. Evidence from the Taiwan capital market reveal that the earnings and book value of equity audited by Big 4 auditors explain more variations in stock return than those audited by Non-big 4. Also, Ardiana (2014) investigates the effect of external audit characteristics on the value of company. Multiple 
regression analysis was used to establish the relationship between audit tenure, firm size opinion, and firm value. The study finds that higher value of company is achieved by shorter audit tenure, brand name audit firms, and unqualified audit opinion.

Furthermore, the results of the study of Okolie (2014) on audit firm size and market price per share of quoted companies in Nigeria indicate that audit firm size exerts significant influence on the market price per share of quoted companies in Nigeria with the study providing evidence of a positive significant effect of big 4 firm on share price. Guo, Koch and Zhu (2015) studied on how introducing a joint audit requirement will affect audit market structure and social welfare in the UK market using the structural estimation approach model, and categorising audit firm size into small sized, medium sized and big 4 groups. Findings reveal that medium-sized audit firms and small audit firms gained market share at the expense of three of the big four audit firms. Interestingly, the largest audit firm was able to maintain its market share.

Analyzing the influence of audit report on the relevance of accounting information reported by listed Romanian companies, Robu and Robu (2015) used ANCOVA regression analysis, and the findings reveal that audited financial statements have a significant influence on the stock return, depending on the opinion in the audit report and on the auditor's Big 4 membership. Similarly, Robu and Robu (2016) analyzed whether the adoption of IFRS makes auditors' affiliation to the Big 4 and the audit opinion to be value relevant for investors of 59 companies listed on Bucharest Stock Exchange (BSE). The results achieved from the Ohlson and Feltham (1995) regression analysis indicate that information provided by the audit report, auditors' affiliation to the Big 4 and the audit opinion, are value relevant for investors and have a significant impact on the share price.

\subsection{Theoretical Framework}

The agency theory is the most prominent and widely used audit theory of the existing theories in auditing. Watts and Zimmerman (1986) suggest that the auditor is appointed in the interests of both the management and the third parties. However, since the focus of financial reporting has shifted from being carried out for monitoring purposes, to focus more on the needs and the provision of information to enable users to take economic decisions (Higson, 2003), an alternative or complement to the monitoring hypothesis is the information hypothesis. Consequently, the audit is valued by investors as a means of improving the quality of financial information (Wallace, 1980).

Investors require audited financial information in order to take and assess decisions regarding their investments' and expected returns and/or risks, respectively. Therefore, they value the audit as a means of improving the quality of financial information, and also as a means of improving the financial data used in internal decision making. Information hypothesis emphasizes that financial information is needed by investors to determine market values, which are a means of making rational investment decisions, even in the absence of an explicit contract with the agent (Wallace 1980). As such, if investors are aware of the information asymmetry and the fact that insiders can profit on value relevant information before public disclosure, they can alternatively adapt their trading behaviour, leave the market (Merton, 1987) or react to the information asymmetry and the risk of insider trading by gathering information themselves or obtaining information from intermediaries (Barth, Kasznik \& McNichols, 2001). The information environment is closely related to the latter choice of action and refers to the richness of the information available concerning the firm. Specifically, for larger firms there is greater distribution of firm-specific information on the market from both accounting and non-accounting sources (Mitra \& Cready, 2005).

\section{Methodology}

The study adopts a correlational research design, and secondary data was obtained from a population of one hundred and thirty eight (138) actively trading companies listed on the Nigerian Stock Exchange that had readily available 2015 data. However, a total of twenty (20) firms with unavailable inputs in some years were filtered out, resulting in one hundred and seventeen (117) quoted companies to form the sample size of the study over a period of seven years from 2009 to 2015. Relevant data were extracted from audited annual reports and accounts of sampled firms and the share price data was extracted from www.cashcraft.com which is a financial data base in Nigeria owned and managed by Asset Management Limited a member of the Nigerian Stock Exchange. The study uses the Ohlson (1995) price model modified to include auditor type variables as well as control variables in order to test the hypotheses of the study. Following the model, market value is regressed on earnings, book values and auditor type to substantiate the relationship between accounting measures and market price. 
A simultaneous Pooled OLS regression using the Seemingly Unrelated Estimates Regression (SUEST) approach was utilized in running the analysis. SUEST was used because apart from testing coefficients across different equations, it also takes into account the differences in the compositions of the partitioning variables.

\subsection{Model Specification}

The following equations present the regression models for this study which are estimated individually and then simultaneously at once, to facilitate the test of coefficients across equations.

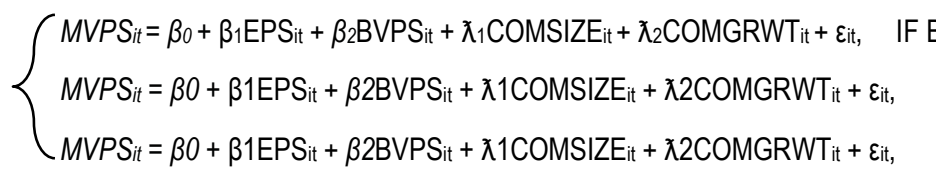

BIG4_NON BIG4.

IF BIG4

Where:

MVPS it represents market value (share price) of company $i$ at time $t$;

EPS it represents earnings per share of firm $i$ at time $t$;

$B V P S_{i t}$ represents book value per share of firm $i$ at time $t$,

COMSIZE it represents company size of firm $i$ at time $t$,

COMGRWT it represents company growth of firm $i$ at time $t$,

$i$ denotes a specific firm and $t$ is the financial year

$\beta_{0}$ is the intercept

$\beta_{1}, \beta_{2}, \beta_{3}, \ldots$. represent the coefficients of independent variables

$\lambda_{1}, \lambda_{2} \lambda_{3} \ldots . .$. represent the coefficients of control variables

$\varepsilon$ is the random error term

Table 1: Study Variables and Measurement

\begin{tabular}{|l|l|l|l|}
\hline S/N & Variables & Type & Measurement \\
\hline 1 & Market Value per Share (MVPS) & Dependent & Share price at four months after the end of financial year \\
\hline 2 & Earnings Per Share (EPS) & Independent & From Income Statement \\
\hline 3 & Book Value Per Share (BVPS) & Independent & Equity divided by outstanding shares at the end of financial year. \\
\hline 4 & Auditor Type (AUDIT_TYPE) & Independent & $\begin{array}{l}\text { Nominal scale of 1, 2, 3, for joint audit (big4- Non_big4), Single big4, } \\
\text { and Single non_big4 respectively }\end{array}$ \\
\hline 5 & Company Size (COMSIZE) & Control & Natural Log of total assets at the end of financial year \\
\hline 6 & Company Growth (COMGRTH) & Control & $\begin{array}{l}\text { Market value per share to book value of equity at end of financial } \\
\text { year }\end{array}$ \\
\hline
\end{tabular}




\section{Source: Researchers' Compilation}

\section{Discussion of Results}

The study used a balanced panel data of one hundred and seventeen listed firms on the Nigerian Stock Exchange (NSE) over a period of seven (7) years from 2009 to 2015 resulting in a total of 819 observations. The results obtained from the analysis of data are presented and discussed as follows:

\subsection{Descriptive Statistics}

Table 2 presents the descriptive statistics of the study variables. Looking at the table, it can be observed that the average of market values per share (MVPS) for the entire firms under study stand at approximately 20.27 (Nigerian Naira).The minimum share price for all sampled firms is 50 kobo, the maximum is 1,040 Naira. This wide variation can be evident in the high standard deviation of about 69.25 which is outside the range of a normal distribution. Earnings per share (EPS) of the firms under study averaged at 1.14 Naira. This average factored in the losses incurred by some firms during the study period. This accounts for the lowest EPS figure of -24 Naira, indicating that some investors lost about 24 Naira of accounting earnings for every 20.27 Naira market value invested (if we are to go by the average of MVPS, ignoring initial market values). Nevertheless, some investors gained as high as 37.57 Naira for every 20.27 Naira invested during the period. That is approximately $85 \%$ earnings returns (if we are to ignore the capital appreciation). The standard deviation for EPS, though far lower than that of MVPS, is still out of normal range. Thus, this analysis should be viewed in light of this deviation's extent.

The book value per share (BVPS) yields an average of 7.93 Naira. Adding this to the average earnings of 1.14 Naira gives us 9.7 Naira worth of book assets for each share of 20.27 Naira. Ignoring the variation, one may be quick to perceive overpricing of these shares, considering the high market to book ratio. Looking at the dispersion indices however, it can be evident that while some firms have a negative net worth of as low as -30.71 Naira, other firms have a positive net worth of as high as 321.02 Naira for every 20.27 Naira market value of shares.

The variable AUDIT_TYPE is a factor variable on a nominal scale of 1 to 3 . It's minimum and maximum is there to verify the correctness of the coding. No out of range code is evident there in. The control variables, firm size (COMSIZE) and firm growth (COMGRTH), respectively produced average of a natural logarithm of assets' book value of about 4.24 and a ratio of 5.497. While the statistics reveal a less noisy distribution of COMSIZE (with a standard deviation of 0.9), the COMGRTH statistics show a significant dispersion among the firms, in terms of growth, having a standard deviation of 78.9. This is further highlighted in the minimum and maximum figures. The figures show that some firms experienced very low (as low as a market-to-book ratio of -1176.194) growth opportunities as gauged by the market, while others experienced very high growth opportunities (as high as a market-to-book ratio of 1690.626), based on market's assessment.

The above statistics should be viewed in light of the distribution of the firms based on their respective audit types. Of the 819 firms' years observations, only 30 of these engaged the service of joint audit teams, the rest engaged single audit teams. Among the single audit classification, about 296 firms' years engaged the service of non big 4, while majority of the firms' years patronized big 4 audit teams. In all likelihood therefore, the above may hold more for firms using single audit firms and even better possibly for firms patronizing single big four audit firm.

Table 2: Descriptive Statistics

\begin{tabular}{|l|l|l|l|l|}
\hline VARIABLES & MEAN & STANDARD DEV & MINIMUM & MAXIMUM \\
\hline MVPS & 20.272 & 69.246 & 0.5 & 1040 \\
\hline EPS & 1.143 & 3.725 & -24 & 37.57 \\
\hline BVPS & 7.934 & 18.370 & -30.71 & 321.02 \\
\hline AUDIT TYPE & 2.324 & 0.541 & 1 & 3 \\
\hline COMSIZE & 4.237 & 0.900 & 2.069 & 9.357 \\
\hline COMGRTH & 5.497 & 78.943 & -1176.194 & 1690.626 \\
\hline & BIG4_NON_BIG4 & BIG4 & NON_BIG4 & TOTAL \\
\hline
\end{tabular}




\begin{tabular}{|l|l|l|l|l|}
\hline FREQUENCY & 30 & 493 & 296 & 819 \\
\hline
\end{tabular}

Source: Author's computation using Stata-13 Software

It should be noted that, in view of the technique of hypotheses testing which the study has opted for, the perceived noisiness in most of the variables distributions, may not affect the validity of the findings. The study estimated three OLS regression results, simultaneously, with a robust standard error. This takes care of any possible inconsistency or biasness which may affect the error terms due to data noisiness. This result is presented and interpreted in the next subsection.

\subsection{Hypotheses Test Results}

This section presents the results of simultaneous regression results, as well as the equality of coefficient tests carried out by the study. Based on the study's objectives, the analysis was conducted with a view to ascertaining the extent to which auditor type affects the value relevance of earnings and book value, as well as whether, the effect varies significantly among audit type categories. Table 3 presents a summary of the simultaneous regression results using SUEST approach. Detailed results (direct outputs), including the initial non-simultaneous regression results, can be found in the appendix section. Following the table is a discussion of the results.

Table 3: Pooled OLS Regression (SUEST with Robust Standard Error) Results

\begin{tabular}{|l|l|l|l|}
\hline MEAN COEFFEICIENT (T-VALUE) SIG & NON_BIG4 & BIG4+NONBIG4 \\
\hline EPS & BIG4 & 0.859 & -0.625 \\
& 16.292 & $(1.29)$ & $(-1.39)$ \\
\hline BVPS & $(5.33)^{\star * *}$ & 0.895 & 1.074 \\
& 0.221 & $(2.22)^{\star *}$ & $(3.47)^{\star *}$ \\
\hline COMSIZE & $(1.50)$ & 3.050 & -4.301 \\
& -2.178 & $(1.63)$ & $(-3.62)^{\star * *}$ \\
\hline COMGROWTH & $(-0.72)$ & .055 & -0.340 \\
& 0.000 & $(2.57)^{\star * *}$ & $(-0.26)$ \\
\hline CONSTANT & $(0.05)$ & -8.881 & 26.401 \\
& 9.624 & $(-1.29)$ & $(3.74)^{* * *}$ \\
\hline
\end{tabular}

SOURCE: Author's computation using Stata-13 Software

(asterisks ${ }^{* * *},{ }^{* *}$ and ${ }^{*}$ represent $1 \%, 5 \%$ and $10 \%$ level of significance)

From table 3, the earnings response coefficient (EPS loading) for firms that were audited by a joint audit service of Big4 and non big 4 auditors, is positive. The corresponding z-value however is not significant even at $10 \%$. This means that for our sampled firms/years, joint audit service does not have a significant effect on the value relevance of earnings. With this, the hypothesis Ho1a is retained. For firms' years that employed the service of single Big4 auditors, the coefficient is positive and significant. It indicates that for every one unit increase in EPS of the firms audited by a single big4 auditor, MVPS increased by approximately $16.3 \%$ of a unit share's value. This is significant even at $1 \%$ level. This therefore led us to reject the null hypothesis Ho2a and uphold that big4 audit firms have a significant positive effect on the value relevance of earnings. Beta of EPS for non-big4 is negative. It means that investors perceive the reported earnings of firms under the watch of non-big4 in a bad light. However, this finding is not significant. We thus fail to reject the null hypothesis Ho3a.

Regarding the factor loadings of BVPS, while this is significant for all the three categories of auditing, the loading is not significant for firms using single big4 but significant for firms using either of non-big4 of joint audit of big4 and non big4. Based on these, we hence reject $\mathrm{HO} 1 \mathrm{~b}$ and $\mathrm{HO3b}$ and fail to reject $\mathrm{HO2b}$. The control variables, COMSIZE is negatively and significantly value relevant only for firms using a joint audit service. This is plausible, considering that smaller firms taking a serious approach to the auditing of its books, is indeed a sign of reliability. COMGRTH is positive and significant 
only for non-big4 firms' years. The cogency here could be that high growth firms may not spare the extra penny in hiring big4 audit firms or even big4 plus non-big4 firms.

The following table depicts the result of equality of coefficient tests carried out after the SUEST estimates. This result is used in testing whether the effects of audit type on the value relevance of earnings and book value is significantly different among firms under the different categories of audit types (H04a\&b, H05a\&b and H06a\&b). Following the table is a discussion on the table's content. Detailed results can be found in the appendix section.

Table 4: Equality of Coefficient Test Results

\begin{tabular}{|l|l|l|}
\hline TEST PARAMETERS & EPS & BVPS \\
\hline BIG4_NONBIG4 = BIG4 & $29.97^{\star \star *}$ & $6.16^{\text {***}}$ \\
\hline BIG4_NONBIG4 = NON-BI4 & $3.41^{*}$ & 0.12 \\
\hline BIG4 = NON-BIG4 & $24.32^{\star * *}$ & 2.47 \\
\hline
\end{tabular}

SOURCE: Author's computation using Stata-13 Software

(asterisks ${ }^{* * *},{ }^{* *}$ and ${ }^{*}$ represent $1 \%, 5 \%$ and $10 \%$ level of significance)

From table 4, the chi-2 statistics for the tests of whether the effect of big4 audit firms on the value relevance of EPS is significantly different from the effect of joint audit team (big4_non_big4) on the value relevance of EPS, is significant even at $1 \%$. This shows that the two effects are significantly different. To fully discern which of the effect is greater than which, we refer back to the initial regression coefficients initially estimated (table 3). It shows that the earnings response coefficient of big4 audited firms is greater (bigger z-value) than that of the firms under joint audit. Thus, we conclude here that the EPS of firms audited by a Big4 audit firm is of significantly greater value relevance than that the EPS of firms audited by joint audit (big4 and non-big4). We therefore reject $\mathrm{HO4a}$.

$\mathrm{H} 04 \mathrm{~b}$ too is rejected since the reported chi-2 is significant. However, here, it is the coefficient of BVPS for firms under the joint audit that is significantly greater (see table 3). For firms under either of joint audit or non-big4, there seems not to be any significant difference in both EPS and BVPS, i.e. the market is indifferent as regards to the earnings and book value information supplied by firms audited by a joint audit or a single non-big4. Thus, the study fails to reject both $\mathrm{H} 05 \mathrm{a}$ and $\mathrm{H} 05 \mathrm{~b}$. The evidence as well favors rejecting $\mathrm{H} 06 \mathrm{a}$, in as much as the chi-2 result for testing the equality of EPS coefficients of big4 versus non-big4 is significant. Combining this result with the regression result will led to conclusion that in fact, the effect of big4 on the value relevance of earnings is significantly greater than the effect of non-big4. The same however cannot be said on the book value (insignificant chi-2 of 2.47). Here, though non-big4 has bigger effect on the value relevance of BVPS, the evidence is however not statistically significant. For this fact, the study retains H06b.

\section{Conclusion}

The study investigates the extent to which auditor type affects the value relevance of earnings and book value, using listed firms in Nigeria for a period seven years. Based on the study's findings, it was discovered that, while Nigerian investors perceive the earnings of firms audited by a single big4 to be of high quality, they seem indifferent as to whether it is audited by a joint audit or a single non-big4 auditor. This supports the free rider hypotheses. In a joint auditing, it is possible for one auditor to freely ride on the effort of the other without providing appropriate level of effort, by relying on the other auditor's work. The market therefore, may value a single auditor with established reputation to guard (like the big4) than a joint audit team, or another single auditor with not much to loose as a reputation. In addition, considering big4 as a symbol of quality, the findings implies that either Nigerian investors do not value firms' net worth as they value earnings and as such they are mostly investors with short term profit motive, or that they trust a joint audit team or a single small auditor to do a better job at scrutinizing firms reported net worth.

In view of the foregoing, we recommend that investors looking for more value relevant EPS should focus on firms audited by single big4, as firms audited by big4 are more likely to have greater value relevant earnings (with stronger positive connection to price). Our findings are in line with the findings of related studies of Deng, Lu and Simunic (2012); Lee and Lee (2013); Alsadoun and Aljabr (2014) and Okolie (2014). Lastly, this study is not without limitation. The study used a pooled OLS regression in estimating the relationship. Though with robust standard error, the technique failed to take account of the possibility of unobservable panel effects which may also contribute to the relationship. The study therefore 
recommends further studies to take this into account. The validity of the technique is however unaffected by this limitation and hence the results and findings can be relied upon.

\section{References}

[1] Aleksanyan, M., \& Karim, K. (2013) Searching for value relevance of book value and earnings: a case of premium vs. discount firms. Review of Quantitative Finance and Accounting, 489-511.

[2] Al-Thuneibat, A. A., Khamees, B. A., \& Al-Fayoumi, N. A. (2008). The effect of qualified auditor's opinions on market values: Evidence from Jordan. Managerial Auditing Journal, 84 - 101.

[3] Alsadoun, N. \& Aljabr, Y. (2014). Joint Audit and Cost of Equity Capital: Evidence from Saudi Arabia.

[4] Ardiana, P.A. (2014). The role of external audit in improving firm's value: Case of Indonesia. 1-15.

[5] Banimahd, B., Poorzamani, Z., \& Ahmadi, A. S. (2013). The value relevance of audit report, auditor type and audit tenure: Evidence from Iran. Asian Journal of Finance and Accounting, Vol 5, No. 1, 89 103.

[6] Barth, M. E., (1991). Relative measurement errors among alternative pension asset and liability measures. The Accounting Review, 433-463.

[7] Barth, M. E., (1994). Fair value accounting: evidence from investment securities and the market valuation of banks. The Accounting Review, 1-25.

[8] Barth, M., Kasznik, R. \& McNichols, M. (2001). Analyst coverage and intangible assets. Journal of Accounting Research 39:1, 1-34.

[9] Barth, M., Landsman, W., \& Lang, M. (2006). International accounting standards and accounting quality. Working Paper, Stanford University and University of North Carolina at Chapel Hill.

[10] Bauwhede, H. V., Willekens, M. \& Gaeremynck, A. (2000). Audit quality, public ownership and firms' discretionary accruals management, Working paper.

[11] Beaver, W. (1998). Financial reporting: An accounting revolution. 3rd ed. Upper Saddle River (US): Prentice Hall.

[12] Becker, C. L., Defond, M. L., Jiambalvo, J. and Subramanyam, K. R. (1998). The effect of audit quality on earnings management, Contemporary Accounting Research, 15 (1), 1 - 24.

[13] Boone, J. P., Khurana, I. K., Raman, K. K. (2010). Do the big 4 and the second-tier firms provide audits of similar quality? Journal of Accounting and Public Policy, 29(4), 330-352.

[14] Chang, H., Cheng. C.S., \& Reichelt, K.J. (2010). Market reaction to auditor switching from Big 4 to third-tier small accounting firms. Auditing: A Journal of Practice \& Theory, 2, 83-114.

[15] Chen, C. Y., Lin, C. J., \& Lin, Y. C. (2008). Audit partner tenure, audit firm tenure and discretionary accruals: does long auditor tenure impair earnings quality? Contemporary Accounting Research, 25, 415-445.

[16] Cheng, Y. S., Liu, Y. P., \& Chien, C. Y. (2009). The association between auditor quality and human capital. Managerial Auditing Journal, 24 (6), 523-541.

[17] Colbert, G. \& Murray, D. (1998). The association between auditor quality and auditor size: an analysis of small CPA firms. Journal of Accounting, Auditing And Finance, Vol.13, Pp.135-150.

[18] Dang, L. E., Brown, K. F., \& McCullough, B. D. (2011). Apparent audit failures and value relevance of earnings and book value. Review of Accounting and Finance, 10(2), $134 \quad-154$.

[19] DeAngelo, L. (1981). Auditor Size and Audit Quality. Journal of Accounting and Economic,3(3), 183-199 http://dx.doi.org/10.1016/0165-4101(81)90002-1. 
[20] Defond, M. L. (1993). The association between changes in client firm agency costs and auditor switching. Journal of Auditing Practice and Theory, 11 (1).

[21] DeFond, M., Raghunandan, K., \& Subramanyam, K. R. (2002). Do non-audit service fees impair auditor independence? Evidence from going concern audit opinions. Journal of Accounting Research, 40: 1247-1274.

[22] Deng, M., Lu, T., Simunic, D. A., \& Ye, M. (2012). Do Joint Audits Improve or Impair Audit Quality?

[23] Ebrahim, A. (2001). Auditing quality, auditing tenure, client importance and earnings management. Paper presented at Rutgers University.

[24] Eilifsen, A., \& Knivsfla, K. (2008). Non-audit services and audit quality: Investors' concerns Post-Enron. August.

[25] El-Shamy, M. \& Kayed, M.A. (2005). The value relevance of earnings and book values in equity valuation: An international perspective - The case of Kuwait. International Journal of Commerce and Management, 15(1), 68-79.

[26] Escaffre, V., \& Sefsaf, R. (2011). Comparing the value relevance of earnings and book value in IFRS and GAAP standards, Bankers Markets \& Investors: An Academic \& Professional Review, 4-18.

[27] Farouk, M.A., \& Hassan, S.U. (2014). Impact of audit quality and financial performance of quoted cement firms in Nigeria. International Journal of Accounting and Taxation, June, Vol. 2, No. 2, 01-22.

[28] Fatallah, Y., Higgins, J., \& Dickins, D. (2008). The role of asset reliability and auditor quality in equity valuation. 8th Global Conference on Business \& Economics, pp. 1 - 28, Florence, Italy.

[29] Ferguson, M. J., Seow, G. S., \& Young, D. (2004). Non-Audit Services and Earnings Management: U.K. Evidence. Contemporary Accounting Research, 21: 813-841.

[30] Francis, J.R. (2004). What do we know about audit quality? The British Accounting Review, 368.

[31] Francis, J. R. \& Wilson, E.R. (1988). Auditor changes: A joint test of theories relating to agency costs and auditor differentiation. Accounting Review, 63(4): 663-682.

[32] Francis, J. \& Schipper, K. (1999). Have financial statements lost their relevance. Journal of Accounting Research, 37(2), 319-352.

[33] Francis, J.R. \& Yu, M.D. (2009). Big 4 audit size and audit quality. The Accounting Review, 84 (5), 1521-1552.

[34] Gerayli, M. S., Yanesari, A. M., \& Ma'atoofi, A. R. (2011). Impact of audit quality on earnings management: evidence from Iran, International Research Journal of Finance and Economics, 66, $\mathrm{http} / \mathrm{www}$.eurojournals.com/finance.

[35] Gordon, M. J. (1959). Dividends, earnings and stock prices. Review of Economic Studies, 41, 99-105.

[36] Guo, Q., Koch, C. \& Zhu, A. (2016). Joint audit, audit market structure and consumer surplus. Review of Accounting Studies, 1-43.

[37] Higson, A. (2003). Corporate Financial Reporting - Theory \& Practice. London: Sage Publications Ltd.

[38] Hussainey K.H. (2009). The impact of audit quality on earnings predictability. Managerial Auditing Journal, 24 (4): 340-351.

[39] Holm, C., \& Thinggaard, F. (2011). Joint audits - benefit or burden? http://papers.ssrn.com/sol3/papers.cfm?abstract_id=1702867, accessed 31/12/2015.

[40] Kang-tao, Y. E, \& Ying-Li. C. (2011). Audit quality and value relevance of fair value accounting. Journal of Shanghai Lixin University of Commerce, 3. 
[41] Keener, M.H. (2011). The relative value relevance of earnings and book value across industries. Journal of Finance and Accountancy, 1-19

[42] Knechel, W. R. (2002). Auditing: Assurance and Risk. 2nd ed. SouthWestern College Publishing.

[43] Krishnan, J., \& Schauer, P. C. (2000). The differentiation of quality among auditors: evidence from the not-for profit sector, Auditing: A Journal of Practice and Theory. 19 (2), 9- 26.

[44] Krishnan, G. (2003). Does Big 5 auditor industry expertise constrain earnings management? Accounting Horizons, (Supplement), 1-16.

[45] Lai, S., Lin, C., Li, H. \& Frederick H. Wu, F. H. (2009). The Information Contents of Modified Unqualified Audit Opinions under the Control of Concurrent Information: The Case of Taiwan. Journal of Accounting and Corporate Governance, 6 (1), 31-56.

[46] Lee, H..L., \& Lee, H. (2013). Do big 4 audit firms improve the value relevance of earnings and equity? Managerial Auditing Journal, 28(7), 628- 646.

[47] Lin, L., \& Tepagul, N.K. (2009). Auditor independence and audit quality: A literature review. $\quad$ 1-54.

[48] Lobo, G., Pangam, L., Zhang, D. \& Casta, J. (2013). Joint auditor pair on conservatism. Evidence from impairment tests.

[49] Martinez, M., P., Vico, M.A., \& Benau, G. M. (2004). Reactions of the Spanish qualified audit reports. European Accounting Review, Vol. 13, Issue 4, pp. 689-711.

[50] Merton, R. (1987). A simple model of capital market equilibrium with incomplete information. Journal of Finance, 42, 483-510.

[51] Mitra, S., \& Cready, W. (2005). Institutional stock ownership, accrual management, and information environment. Journal of Accounting, Auditing and Finance, 20:3, 257286.

[52] Moizer, P. (1997). Auditor Reputation: the international empirical evidence. International Auditing, 1(1), 61-74.

[53] Nigerian Standards on Auditing (NSAs). Issued by the Institute of Chartered Accountants of Nigeria (ICAN) 2013.

[54] Nelson, M., Elliott, J., \& Turpley, R. (2002). Evidence from auditors about manager's and auditor's earnings management. The Accounting Review, 77 (Supplement), 175 - 202.

[55] Ohlson, J. A. (1995). Earnings, book values, and dividends in security valuation. Accounting Research, 11, 661-687.

Contemporary

[56] O'Keefe, T.B., King, R.D. \& Gaver, K.M. (1994). Audit fees, industry specialization, and compliance with gaas reporting standards. Auditing: A Journal of Practice and Theory, 13 (Fall), 41 - 55.

[57] Okolie, A. O. (2014). Audit firm size and market price per share of quoted companies in Nigeria. International Journal of Business and Social Research, Vol. 4 (5), 100 -117.

[58] Olowookere, J. K., \& Inneh, G. E. (2016). Determinants of external auditors choice in Nigerian quoted manufacturing companies. Kuwait Chapter of Arabian Journal of Business and Management Review, 5(9), 10-22.

[59] Ratzinger-Sakel, N., Audosset-Coulier, S., Kettunen, J., \& Lesage, C. (2012). What do we know about joint audit? Edinburgh: ICAS Publishers, ISBN-978-1904574-92-7.

[60] Robu, M. A., \& Robu, I. A. (2015). The influence of the audit report on the relevance of accounting information reported by Listed Romanian Companies. Procedia Economics and Finance, Vol. 20, 562 570 . 
[61] Robu, A.M. \& Robu, I. B. (2016). The value relevance of audit report Under IFRS in the Case of Romanian Listed Companies. Entrepreneurship, Business and Economics, Vol. 2.

[62] Schilder, G. S. (2011). Audit quality: An IAASB perspective. Available at http://www.iaasb.org

[63] Sharma, S. (2011). Determinants of equity share prices in India. Researchers World; $\quad$ Melagaon, 2.4 (Oct): $51-60$.

[64] Shamki, D. \& Abdul Rahman, A. (2011).Value relevance of earnings and book value: Evidence from Jordan. International Journal of Business Management, 7(3), 133-141.

[65] Simunic, D. (1980). The pricing of audit services: Theory and evidence. Journal of Accounting Research (Spring), $161-190$.

[66] Wallace, W. (1980). The economic role of the audit in free and regulated markets. The Touche Ross and Co. Aid to Education Program. Reprinted in Auditing Monographs

(New York Macmillan Publishing Co., 1985. Available at: $<$ http://raw.rutgers.edu/raw/wallace/homepage.html>.

[67] Watts, R., \& Zimmerman, J. (1983). Agency problems, auditing and the theory of the firm: Some evidence. Journal of Law and Economic, 26(3), 613 - 633.

[68] Qua, X., \& Zhang, G. (2012). Changes in the value-relevance of earnings and book values over the institutional transition and the suitability of fair value accounting in emerging markets: A case from China.

[69] Zahir, M. \& Khanna, Y. (1982). Determinants of stock prices in India. The Chartered Accountant, 30 (8), 521-523.

[70] Zerni, M., Haapamaki, E., Jarvinen, T., \& Neimi, L. (2012). Do joint audits improve audit quality? Evidence from voluntary joint audits. European Accounting Review, iFirst Artile, 1 - 35.

\section{APPENDICES}

\section{DESCRIPTIVE STATISTICS}

- summarize mvps eps bvps auditype comsize comgrth

\begin{tabular}{r|rrrrr} 
Variable & Obs & Mean & Std. Dev. & Min & Max \\
\hline mvps & 819 & 20.27226 & 69.24603 & .5 & 1040 \\
eps & 819 & 1.143407 & 3.724673 & -24 & 37.57 \\
bvps & 819 & 7.934396 & 18.37026 & -30.71 & 321.02 \\
auditype & 819 & 2.324786 & .5412189 & 1 & 3 \\
comsize & 819 & 4.237008 & .9007122 & 2.069143 & 9.357426 \\
\hline comgrth & 819 & 5.496741 & 78.94258 & -1176.194 & 1690.626
\end{tabular}

\section{REGRESSION (SUEST) RESULTS}


- regress mvps eps bvps comsize comgrth comgrth if auditype==1 note: comgrth omitted because of collinearity

\begin{tabular}{|c|c|c|c|}
\hline Source & SS & $d f$ & MS \\
\hline Model & 1979.46128 & 4 & 494.86532 \\
\hline Residual & 1274.86035 & 25 & 50.9944142 \\
\hline Total & 3254.32163 & 29 & 112.217987 \\
\hline
\end{tabular}

$\begin{array}{llr}\text { Number of obs } & = & 30 \\ \text { F }(4, \quad 25) & = & 9.70 \\ \text { Prob }>\text { F } & =0.0001 \\ \text { R-squared } & =0.6083 \\ \text { Adj R-squared } & =0.5456 \\ \text { Root MSE } & =7.141\end{array}$

\begin{tabular}{|c|c|c|c|c|c|c|}
\hline mvps & coef. & std. Err. & t & $P>|t|$ & Conf. & Interval] \\
\hline eps & -.6246955 & .8446104 & -0.74 & 0.466 & -2.364203 & 1.114812 \\
\hline bvps & 1.073473 & .2337171 & 4.59 & 0.000 & .5921232 & 1.554822 \\
\hline comsize & -4.301125 & 1.410379 & -3.05 & 0.005 & -7.205854 & -1.396396 \\
\hline comgrth & -.3404236 & 1.021889 & -0.33 & 0.742 & -2.445044 & 1.764196 \\
\hline comgrth & 0 & (omitted) & & & & \\
\hline _cons & 26.40131 & 7.935308 & 3.33 & 0.003 & 10.05823 & 42.74438 \\
\hline
\end{tabular}

- regress mvps eps bvps comsize comgrth comgrth if auditype==2 note: comgrth omitted because of collinearity

\begin{tabular}{r|rrr} 
Source & SS & df & MS \\
\hline $\begin{array}{r}\text { Model } \\
\text { Residual }\end{array}$ & 2391374.82 & 4 & 597843.706 \\
1347429.74 & 488 & 2761.12652 \\
\hline Total & 3738804.56 & 492 & 7599.19627
\end{tabular}

$\begin{array}{llr}\text { Number of obs } & = & 493 \\ \mathrm{~F}(4,488) & = & 216.52 \\ \text { Prob }>\mathrm{F} & = & 0.0000 \\ \text { R-squared } & 0.6396 \\ \text { Adj R-squared } & =0.6367 \\ \text { Root MSE } & =52.546\end{array}$

\begin{tabular}{|c|c|c|c|c|c|c|}
\hline mvps & coef. & Err. & $t$ & $P>|t|$ & Conf. & Interval] \\
\hline eps & 16.29299 & .6227059 & 26.16 & 0.000 & 15.06948 & 17.51651 \\
\hline bvps & .2218633 & .1152691 & 1.92 & 0.055 & -.0046216 & .4483483 \\
\hline comsize & -2.178716 & 2.782631 & -0.78 & 0.434 & -7.646133 & 3.288701 \\
\hline comgrth & .0004635 & .0251986 & 0.02 & 0.985 & -.0490477 & .0499747 \\
\hline comgrth & 0 & (omitted) & & & & \\
\hline _cons & 9.624123 & 12.34591 & 0.78 & 0.436 & -14.63359 & 33.88183 \\
\hline
\end{tabular}


- regress mvps eps bvps comsize comgrth comgrth if auditype==3 note: comgrth omitted because of collinearity

\begin{tabular}{r|rrr} 
Source & SS & df & MS \\
\hline $\begin{array}{r}\text { Model } \\
\text { Residual }\end{array}$ & 57867.4865 & 291 & 198.857342 \\
\hline Total & 71900.6995 & 295 & 243.731185
\end{tabular}

$\begin{array}{ll}\text { Number of obs } & = \\ \text { F }(4,291) & = \\ \text { Prob }>\text { F } & = \\ \text { R-squared } & = \\ \text { Adj R-squared } & = \\ \text { Rot MSE } & =\end{array}$

296

17.64

0.0000

0. 1952

0.1841

14.102

\begin{tabular}{|c|c|c|c|c|c|c|}
\hline mvps & coef. & sta. & $t$ & $P>|t|$ & [95\% Conf. & Interval] \\
\hline eps & .8593913 & .2934608 & 2.93 & 0.004 & .2818165 & 1.436966 \\
\hline bvps & .8945656 & .1420964 & 6.30 & 0.000 & .6148987 & 1.174233 \\
\hline comsize & 3.050764 & 1.35989 & 2.24 & 0.026 & .3742963 & 5.727232 \\
\hline comgrth & .0545202 & .0240118 & 2.27 & 0.024 & .0072615 & .1017789 \\
\hline comgrth & 0 & (omitted) & & & & \\
\hline _cons & -8.881752 & 5.141609 & -1.73 & 0.085 & -19.00121 & 1.237703 \\
\hline
\end{tabular}

- suest big4_non_big4 big4 non_big4

Simultaneous results for big4_non_big4, big4, non_big4

\begin{tabular}{|c|c|c|c|c|c|c|}
\hline & & Robust & & & & \\
\hline & Coef. & std. Err. & $\mathrm{z}$ & $P>|z|$ & [95\% Conf. & Interval] \\
\hline big4_non_big4_mean & & & & & & \\
\hline eps & -.6246955 & .4481884 & $-1 \cdot 39$ & 0.163 & -1.503129 & .2537377 \\
\hline bvps & 1.073473 & .3097893 & 3.47 & 0.001 & .4662967 & 1.680648 \\
\hline comsize & -4.301125 & 1.188166 & -3.62 & 0.000 & -6.629888 & -1.972362 \\
\hline comgrth & -.3404236 & 1.324179 & -0.26 & 0.797 & -2.935767 & 2.254919 \\
\hline comgrth & & (omitted) & & & & \\
\hline _cons & 26.40131 & 7.065862 & 3.74 & 0.000 & 12.55247 & 40.25014 \\
\hline $\begin{array}{r}\text { big } 4 \text { non_big4_lnvar } \\
\text { cons }\end{array}$ & 3.931716 & .2469673 & 15.92 & 0.000 & 3.447669 & 4.415763 \\
\hline big4_mean & & & & & & \\
\hline eps & 16.29299 & 3.057828 & 5.33 & 0.000 & 10.29976 & 22.28623 \\
\hline bvps & .2218633 & .1476923 & 1.50 & 0.133 & -.0676083 & .511335 \\
\hline comsize & -2.178716 & 3.024636 & -0.72 & 0.471 & -8.106894 & 3.749462 \\
\hline comgrth & .0004635 & .0093709 & 0.05 & 0.961 & -.0179032 & .0188302 \\
\hline comgrth & 0 & (omitted) & & & & \\
\hline _cons & 9.624123 & 10.74014 & 0.90 & 0.370 & $-11 \cdot 42616$ & 30.67441 \\
\hline big4_Invar & & & & & & \\
\hline _cons & 7.923394 & .32616 & 24.29 & 0.000 & 7.284132 & 8.562656 \\
\hline non_big4_mean & & & & & & \\
\hline eps & .8593913 & .6677675 & 1.29 & 0.198 & -.449409 & 2.168192 \\
\hline bvps & .8945656 & .4021385 & 2.22 & 0.026 & .1063886 & 1.682743 \\
\hline comsize & 3.050764 & 1.869209 & 1.63 & 0.103 & -.6128175 & 6.714345 \\
\hline comgrth & .0545202 & .0211733 & 2.57 & 0.010 & .0130213 & .0960191 \\
\hline comgrth & 0 & (omitted) & & & & \\
\hline _cons & -8.881752 & 6.894606 & -1.29 & 0.198 & -22.39493 & 4.631427 \\
\hline non_big4_lnvar & & & & & & \\
\hline - - cons & 5.292588 & .4843859 & 10.93 & 0.000 & 4.343209 & 6.241967 \\
\hline
\end{tabular}




\title{
WALD COEFFICIENT TEST RESULTS
}

\author{
- test [big4_non_big4_mean] eps=[big4_mean] eps

